Artikel Penelitian

\title{
Adiksi Alkohol Meningkatkan Risiko Pemburukan Kualitas Hidup, Studi pada: Pengunjung Kafe- kafe di Jakarta Selatan pada Tahun 2018
}

\section{Alcohol Addiction Increases the Risk of Deteriorating Quality of Life, Study on: Visitors to Cafes in South Jakarta in 2018}

\author{
Grace Fonda ${ }^{1}$, Dharmady Agus', Dwi Jani $\mathrm{J}^{3}$ \\ ${ }^{1}$ Program Studi Kedokteran Fakultas Kedokteran dan Ilmu Kesehatan Universitas Katolik Indonesia Atma Jaya Jakarta \\ ${ }^{2}$ Departemen IImu Kedokteran Jiwa dan Perilaku Fakultas Kedokteran dan IImu Kesehatan Universitas Katolik Indonesia \\ Atma Jaya Jakarta
}

${ }^{3}$ Departemen Medical Education Unit Fakultas Kedokteran dan IImu Kesehatan Universitas Katolik Indonesia Atma Jaya Jakarta

\begin{abstract}
ABSTRAK
Adiksi alkohol adalah suatu fenomena yang berdampak pada perilaku, kognitif, dan fisiologis seseorang yang berkembang setelah berulangkali mengonsumsi minuman beralkohol dan dapat terjadi pada semua kelompok usia. Pengonsumsian alkohol yang berlebihan telah menjadi masalah kesehatan di berbagai negara dan permasalahan ini cenderung mengalami peningkatan dari tahun ke tahun. Berbagai dampak buruk yang diakibatkan oleh adiksi alkohol, baik pada segi fisik, psikologis, hubungan sosial, maupun lingkungan dapat memengaruhi kualitas hidup seseorang. Oleh karena itu, peneliti ingin membuktikan adanya hubungan antara adiksi alkohol dan kualitas hidup. Penelitian ini merupakan penelitian deskriptif analitik dengan desain penelitian potong lintang. Sampel penelitian ini adalah 80 orang pengunjung yang mengonsumsi alkohol di kafe-kafe wilayah Jakarta Selatan pada bulan Mei sampai Juli 2018 yang diambil menggunakan teknik consecutive sampling. Adiksi alkohol dinilai dengan menggunakan kuesioner CAGE dan kualitas hidup dinilai dengan menggunakan kuesioner WHOQOL-BREF versi bahasa Indonesia. Hubungan antara kedua variabel ini dinilai dengan uji analisis statistik Kai-kuadrat. Hasil uji statistik menunjukkan bahwa terdapat hubungan yang bermakna antara adiksi alkohol dan kualitas hidup pada pengunjung kafe-kafe di Jakarta Selatan pada keempat domain WHOQOL$\operatorname{BREF}(p=0,000)$. Hasil penelitian ini menunjukkan bahwa individu dengan adiksi alkohol memiliki risiko lebih besar untuk mengalami perburukan kualitas hidup dibandingkan dengan individu yang tidak mengalami adiksi alkohol, yakni $\mathrm{OR}=33,696, \mathrm{OR}=18,208, \mathrm{OR}=31,200, \mathrm{OR}=7,737$ pada masing-masing domain WHOQOL-BREF. Dapat disimpulkan, terhadap hubungan bermakna antara adiksi alkohol dan kualitas hidup.
\end{abstract}

Kata Kunci: Adiksi alkohol, Jakarta Selatan, kualitas hidup, pengunjung kafe-kafe

\begin{abstract}
Alcohol addiction is a phenomenon that affects a person's behavior, cognitive, and physiology that develops after repeatedly consuming alcoholic beverages and can occur in all age groups. Excessive alcohol consumption has become a health problem in many countries and tends to increase every year. Various adverse effects caused by alcohol addiction can affect someone's quality of life from physical, psychological, social relationships, and environmental aspect. Therefore, this study aimed to prove the association between alcohol addiction and quality of life. This was a descriptive-analytic study with a cross-sectional approach. The sample of this study was 80 subjects who consumed alcohol in cafes in South Jakarta from May to July 2018 taken by consecutive sampling. Alcohol addiction among respondents was screened using the CAGE questionnaire, and quality of life was measured by using the Indonesian version of the WHOQOL-BREF questionnaire. Chisquare test analysis was applied in this study to assess the relationship between these two variables. The statistical test results showed that there was a significant association between alcohol addiction and quality of life among visitors of cafes at South Jakarta at all four domains $(p=0.000)$. Individuals with alcohol addiction have a greater risk of experiencing a worsening of quality of life compared to individuals without alcohol addiction, i.e. OR=33.696, OR=18.208, OR=31.200, $O R=7.737$, respectively in each domain of WHOQOL-BREF. In conclusion, there is a significant association between alcohol addiction and quality of life.
\end{abstract}

Keywords: Alcohol addiction, quality of life, South Jakarta, visitors of cafes

Korespondensi: Grace Fonda. Program Studi Kedokteran Fakultas Kedokteran dan Ilmu Kesehatan Universitas Katolik Indonesia Atma Jaya Jakarta, Jl. Pluit Raya No.2, Jakarta Utara 14440 Tel.08176734152 Email: gracefonda@yahoo.co.id 


\section{PENDAHULUAN}

Data WHO tahun 2011 menunjukkan bahwa pengonsumsian minuman beralkohol mengakibatkan 2,5 juta kematian setiap tahunnya di dunia dan 320 ribu jiwa diantaranya berusia 15-29 tahun. Permasalahan ini cenderung meningkat dari tahun ke tahun sebagaimana ditunjukkan laporan status global oleh WHO tahun 2014, bahwa pengonsumsian alkohol menyebabkan kematian lebih dari 3,3 juta orang setiap tahunnya di dunia atau $5,9 \%$ dari semua kematian yang ada. Pengonsumsian alkohol yang berlebih merupakan penyebab lebih dari 200 penyakit dan cedera di dunia, terutama adiksi alkohol (1). Pengonsumsian alkohol yang berlebih tidak hanya berdampak buruk terhadap masyarakat, tetapi juga terhadap anak-anak dari orang tua dengan adiksi alkohol. Mereka cenderung memiliki keterlambatan perkembangan, masalah sosial, ketidakstabilan emosi, dan keterlibatan dalam berbagai tindak kejahatan $(2,3)$. Hal ini diakibatkan karena anak-anak belajar banyak mengenai kehidupan dari orangtua dan lingkungan sekitarnya. Permasalahan tumbuh kembang secara emosional dan sosial pada anak dari orang tua dengan adiksi alkohol akan berakibat fatal bagi kualitas hidup mereka di masa yang akan datang $(4,5)$.

Data WHO 2010, menunjukkan bahwa 1,3\% laki-laki dan 0,2\% perempuan di Indonesia mengalami adiksi alkohol dengan rata-rata 0,7\% untuk keduanya (1). Data Riskesdas pada tahun 2007 menunjukkan bahwa prevalensi peminum alkohol dalam 12 bulan terakhir di Provinsi DKI Jakarta adalah sebesar $4 \%$, sedangkan yang masih minum dalam satu bulan terakhir adalah sebesar 2,6\%. Pada provinsi DKI Jakarta, prevalensi peminum alkohol di Jakarta Pusat sebesar 5,6\% dan Jakarta Utara sebesar $5,2 \%$. Meskipun tingkat konsumsi dan adiksi alkohol di Indonesia masih tergolong rendah dibandingkan dengan negara lainnya di Asia, namun apabila tidak dicegah dan ditangani lebih lanjut, maka angka mortalitas dan morbiditas akibat pengonsumsian dan adiksi alkohol akan terus bertambah setiap tahunnya seiring dengan bertambahnya jumlah peminum (6).

Adiksi alkohol adalah suatu fenomena yang berdampak pada perilaku, kognitif, dan fisiologis seseorang yang berkembang setelah berulangkali mengonsumsi minuman beralkohol $(5,7)$. Berbagai dampak buruk yang diakibatkan oleh adiksi alkohol, baik pada segi fisik, psikologis, sosial, maupun lingkungan, dapat memengaruhi kualitas hidup seseorang. Kualitas hidup merupakan hal penting dalam penilaian seorang individu dengan adiksi alkohol, karena kualitas hidup merupakan indikator utama dalam penilaian individu terkait kondisinya (8). Studi yang dilakukan oleh da Silva et al. menemukan bahwa 23 dari 36 laki-laki adiksi alkohol tingkat berat memiliki kualitas hidup yang sangat rendah pada ke-4 domain kualitas hidup saat diukur dengan WHOQOL-BREF, terutama dalam aspek psikologis (9). WHO menyatakan bahwa penurunan dari empat domain ini merupakan komponen integral akibat adiksi alkohol. Beberapa penelitian terdahulu mengungkapkan bahwa adiksi alkohol dapat menurunkan kualitas hidup seseorang $(8,10,11)$. Kajian tentang adiksi alkohol dan kualitas hidup di Indonesia masih terbatas, oleh karena itu tujuan dari penelitian ini adalah membuktikan hubungan antara adiksi alkohol dan kualitas hidup di Indonesia.

\section{METODE}

Penelitian ini merupakan penelitian deskriptif analitik dengan desain penelitian potong lintang. Pengambilan sampel dilakukan dengan teknik consecutive sampling. Subjek penelitian adalah pengunjung kafe-kafe di Jakarta Selatan pada bulan Mei sampai Juli 2018 yang memenuhi kriteria inklusi. Kriteria inklusi penelitian ini adalah pengunjung kafe-kafe di Jakarta Selatan yang pernah mengonsumsi alkohol dalam 12 bulan terakhir, berusia di atas 21 tahun, dapat berbahasa Indonesia, dan bersedia menjadi responden dengan menandatangani informed consent. Kriteria eksklusi penelitian ini adalah pengunjung yang mengonsumsi narkotika, psikotropika, dan zat adiktif selain nikotin dan kafein, serta pengunjung dalam kondisi mabuk. Pelaksanaan penelitian ini mendapat persetujuan dari Komisi Etik Fakultas Kedokteran dan Ilmu Kesehatan Universitas Katolik Indonesia Atma Jaya dengan Surat Persetujuan Etik No. 07/12/KEP-FKUAJ/2017, Unit Pelaksana Pelayanan Terpadu Satu Pintu Kota Administrasi Jakarta Selatan dengan Surat Rekomendasi Izin Riset/Penelitian No. 937/-082.61, dan Suku Dinas Kesehatan Kota Administrasi Jakarta Selatan dengan Surat Persetujuan Pengambilan Data pada Pengunjung Kafe-kafe di Jakarta Selatan No. 5061/-1.777.22.

Alat ukur yang digunakan untuk menilai adiksi alkohol adalah kuesioner CAGE. Kuesioner ini memiliki empat buah pertanyaan dengan jawaban "ya" dan "tidak". Setiap pertanyaan mempunyai nilai 0 untuk jawaban "tidak" dan nilai 1 untuk jawaban "ya". Total nilai yang semakin tinggi mengindikasikan semakin tingginya tingkat ketergantungan alkohol. Dari kuesioner ini, seseorang dinyatakan adiksi alkohol positif apabila terdapat dua atau lebih jawaban "ya" dan adiksi alkohol negatif apabila kurang dari dua jawaban "ya" (12).

Kualitas hidup dinilai melalui wawancara menggunakan kuesioner WHOQOL-BREF versi bahasa Indonesia, yang merupakan kuesioner untuk menilai kualitas hidup seseorang lintas kultural dengan 26 pertanyaan. Dari 26 pertanyaan yang ada, dikelompokkan menjadi empat domain utama yaitu fisik, psikologis, sosial, dan lingkungan. Pertanyaan-pertanyaan yang terdapat di WHOQOL-BREF membahas berbagai aspek dalam hidup dan kepuasan mereka akan hidup yang dijalani. Kuesioner ini dapat digunakan pada semua negara dan semua populasi di dunia, ras apapun, dan kepercayaan apapun, terlepas individu tersebut dalam keadaan sehat atau sakit. Kualitas hidup dikatakan buruk apabila skor WHOQOL$\mathrm{BREF}<60$ dan kualitas hidup baik apabila skor WHOQOL$B R E F \geq 60(13,14)$. Data dianalisis dengan uji Kai-kuadrat menggunakan program SPSS untuk mengetahui apakah terdapat hubungan yang bermakna antara adiksi alkohol dan kualitas hidup pada pengunjung kafe-kafe di Jakarta Selatan.

\section{HASIL}

Dari 98 responden yang diikutsertakan dalam penelitian ini, terdapat 18 responden di antaranya tidak memenuhi kriteria inklusi atau memenuhi kriteria eksklusi, sehingga jumlah responden yang terlibat dalam penelitian ini adalah sebesar 80 orang. Responden sebagian besar pada usia relatif muda (21-30 tahun), tingkat pendidikan menengah, dan belum menikah. Meskipun tidak dominan, terdapat lebih dari seperempat responden pengguna kafe adalah perempuan (Tabel 1). Lebih dari setengah 
responden mengalami adiksi alkohol dan kualitas hidup yang buruk. Individu dengan adiksi alkohol memiliki kualitas hidup yang buruk (skor $<60)$, terutama pada domain psikologis.

Tabel 1. Karakteristik demografi responden penelitian

\begin{tabular}{|c|c|c|}
\hline Karakteristik & $\mathbf{N}$ & Persentase \\
\hline \multicolumn{3}{|l|}{ Usia } \\
\hline 21-30 Tahun & 57 & $71,25 \%$ \\
\hline 31-40 Tahun & 14 & $17,5 \%$ \\
\hline 41-50 Tahun & 7 & $8,75 \%$ \\
\hline$>50$ Tahun & 2 & $2,5 \%$ \\
\hline \multicolumn{3}{|l|}{ Jenis kelamin } \\
\hline Laki-laki & 57 & $71,3 \%$ \\
\hline Perempuan & 23 & $28,7 \%$ \\
\hline \multicolumn{3}{|l|}{ Status pernikahan } \\
\hline Menikah & 28 & $35 \%$ \\
\hline Belum menikah & 52 & $65 \%$ \\
\hline \multicolumn{3}{|l|}{ Pendidikan terakhir } \\
\hline SMP & 1 & $1,25 \%$ \\
\hline SMA/SMK/SLTA & 37 & $46,25 \%$ \\
\hline D3 & 9 & $11,25 \%$ \\
\hline S1 & 31 & $38,75 \%$ \\
\hline $\mathrm{S} 2$ & 1 & $1,25 \%$ \\
\hline S3 & 1 & $1,25 \%$ \\
\hline \multicolumn{3}{|l|}{ Pekerjaan } \\
\hline Pegawai Swasta & 30 & $37,5 \%$ \\
\hline Wiraswata & 13 & $16,25 \%$ \\
\hline Mahasiswa/i & 28 & $35 \%$ \\
\hline Tidak Bekerja & 2 & $2,5 \%$ \\
\hline Lainnya & 7 & $8,75 \%$ \\
\hline \multicolumn{3}{|l|}{ Adiksi Alkohol } \\
\hline Adiksi & 54 & $67,5 \%$ \\
\hline Tidak Adiksi & 26 & \\
\hline \multicolumn{3}{|l|}{ Kualitas Hidup } \\
\hline Buruk & 41 & $51,2 \%$ \\
\hline Baik & 39 & \\
\hline \multicolumn{3}{|c|}{$\begin{array}{l}\text { Skor kualitas hidup individu } \\
\text { dengan adiksi alkohol (mean, } \\
\text { SD) }\end{array}$} \\
\hline Domain fisik & 57,83 & 10,756 \\
\hline Domain psikologis & 54,00 & 12,906 \\
\hline Domain sosial & 55,07 & 15,412 \\
\hline Domain lingkungan & 55,46 & 12,156 \\
\hline Total & 55,59 & 9,561 \\
\hline
\end{tabular}

Hasil uji Kai-kuadrat dari adiksi alkohol dan masing-masing domain kualitas hidup menunjukkan adanya hubungan yang bermakna antara adiksi alkohol dengan kualitas hidup yang buruk pada semua domain (Tabel 2). Individu dengan adiksi alkohol memiliki probabilitas yang lebih besar untuk mengalami kualitas hidup yang buruk, dibandingkan yang tidak mengalami adiksi alkohol.

Tabel 2. Hubungan antara adiksi alkohol dan kualitas hidup

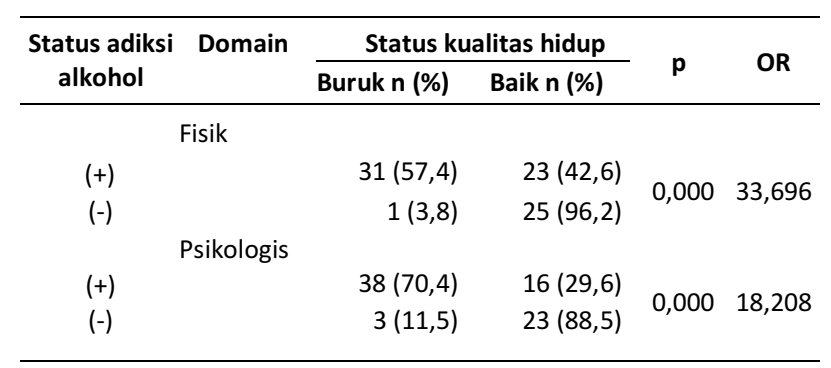

Tabel 2. Hubungan antara adiksi alkohol dan kualitas hidup (Lanjutan)

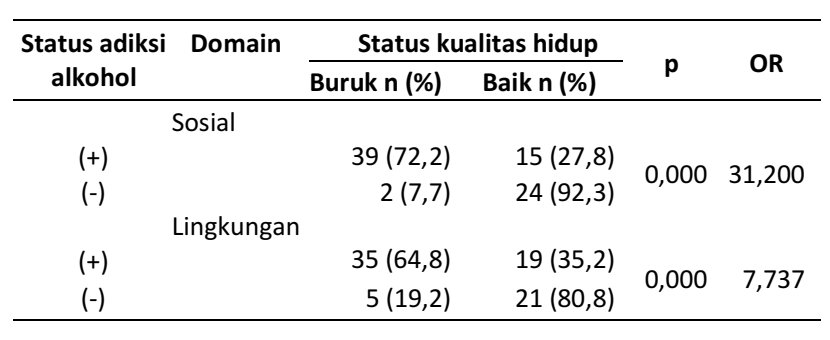

\section{DISKUSI}

Hasil penelitian menunjukkan bahwa sebagian besar subjek penelitian mengalami adiksi alkohol dan memiliki kualitas hidup yang buruk. Kualitas hidup yang terburuk didapatkan pada domain psikologis. Penelitian ini menemukan bahwa adiksi alkohol berhubungan dengan kualitas hidup yang buruk pada semua domain yaitu fisik, psikologis, sosial, dan lingkungan. Hal ini sesuai dengan penelitian Foster et al., yang menggunakan beberapa instrumen pengukuran kualitas hidup (LSS, QALYs, SF-36, dan lain-lain) dan menemukan bahwa individu yang mengalami adiksi alkohol akan memiliki kualitas hidup yang lebih buruk dibandingkan dengan individu yang tidak mengalami adiksi alkohol $(8,17)$. Pada penelitian berikutnya tahun 2015 dengan menggunakan instrumen WHOQOL-BREF, Foster juga menemukan hasil yang sama, begitu pula penelitian potong lintang oleh Yatan et al., pada tahun 2017 di India $(15,18)$. Hubungan antara adiksi alkohol dan kualitas hidup yang buruk ini dapat timbul dikarenakan dampak yang diakibatkan oleh adiksi alkohol itu sendiri. Semakin banyak masalah yang diakibatkan oleh adiksi alkohol, semakin buruk pula kualitas hidupnya akan terjadi. Kualitas hidup meningkat seiring dengan penurunan pengonsumsian alkohol, baik dengan mengontrol jumlah alkohol yang dikonsumsi maupun tidak mengonsumsinya sama sekali (abstinen) $(8,17)$.

Penelitian menemukan kualitas hidup yang buruk $(<60)$ dalam semua domain pada individu dengan adiksi alkohol. Adiksi alkohol dapat melumpuhkan seluruh aspek kehidupan seseorang, baik secara langsung maupun tidak langsung. Penurunan kualitas hidup tidak berhubungan secara langsung dengan derajat keparahan penggunaan alkohol, melainkan berhubungan dengan konsekuensi yang diakibatkan karena pengonsumsian alkohol secara berlebih. Konsekuensi alkohol terhadap segi fisik, psikologis, sosial, maupun lingkungan akan menyebabkan terjadinya penurunan kualitas hidup seseorang. Semakin berat adiksi alkohol yang dialami seseorang, semakin banyak pula dampak yang diakibatkan oleh alkohol terhadap dirinya. Semakin besar dampak dari alkohol, semakin buruk kualitas hidup seseorang akan terjadi $(8,15)$. Meskipun demikian, setiap individu akan mengalami perburukan kualitas hidup pada aspek kehidupan yang berbeda-beda $(11,16)$.

Hasil penelitian ini menunjukkan bahwa terdapat hubungan yang bermakna antara adiksi alkohol dan kualitas hidup pada domain fisik. Seiring dengan bertambahnya angka morbiditas dan mortalitas individu dengan adiksi alkohol, kualitas hidup akan mengalami perburukan pula, terutama pada domain fisik. Dampak yang diakibatkan dari alkohol dapat berupa gejala fisik pada jangka pendek maupun jangka panjang, seperti 
stroke, kanker, sirosis hati, berbagai penyakit kardiovaskuler, gangguan pencernaan, penurunan sistem kekebalan tubuh, amnesia, defisit kognitif yang bersifat sementara, gangguan tidur, dan neuropati perifer $(11,19)$. Individu dengan adiksi alkohol memiliki risiko yang tinggi untuk terkena penyakit hati atau yang dikenal dengan sebutan ALD (Alcoholic Liver Disease). Hal ini dapat terjadi karena metabolisme alkohol yang kedua terjadi di hati dengan menggunakan sitokrom P450 2E1. Semakin banyak alkohol yang dikonsumsi, semakin banyak pula lemak yang terdeposit pada hepar. Kondisi ini akan mengakibatkan peningkatan proses inflamasi di hepar, yang pada taraf selanjutnya dapat berdampak pada kematian sel hepar $(20,21)$.

Adiksi alkohol tidak hanya berdampak bagi kesehatan jasmani seseorang, tetapi juga psikologisnya. Hasil penelitian ini menunjukkan bahwa terdapat hubungan yang bermakna antara adiksi alkohol dan kualitas hidup pada aspek psikologis. Selain itu, individu yang mengalami adiksi alkohol memiliki kecenderungan 18 kali lebih tinggi untuk memiliki kualitas hidup yang buruk dibandingkan dengan individu yang tidak mengalami adiksi alkohol pada aspek psikologis. Beberapa penelitian menunjukkan bahwa terdapat korelasi yang kuat antara adiksi alkohol dan buruknya psikologis seseorang. Salah satu dampak yang diakibatkan oleh adiksi alkohol adalah adanya perubahan mood dan perilaku, seperti gangguan depresi dan cemas $(11,22)$. Selain itu, individu yang mengalami adiksi alkohol juga dapat menjadi lebih agresif dibandingkan dengan individu normal lainnya. Hal ini diakibatkan pada dosis rendah alkohol dapat menyebabkan efek Central Nervous System (CNS) stimulan yang mampu meningkatkan mood seseorang. Sedangkan pada dosis tinggi alkohol menyebabkan CNS depresan karena reward neurotransmitter akan mengalami penurunan seiring dengan berkurangnya efek alkohol yang erat kaitannya dengan gangguan depresi. Beberapa penelitian membuktikan bahwa adiksi alkohol mampu meningkatkan risiko seseorang untuk mengalami gangguan depresi atau bahkan memperburuk gejala gangguan depresi yang ada $(22,23)$. Penelitian yang dilakukan oleh Kuria et al., menunjukkan bahwa terdapat hubungan yang bermakna antara adiksi alkohol dan terjadinya gangguan depresi. Pada penelitiannya terhadap 156 peserta di Nairobi, Kenya, prevalensi gangguan depresi pada orang dengan adiksi alkohol adalah sebesar $63,8 \%$ (25). Semakin tinggi tingkat depresi seseorang, semakin buruk kualitas hidupnya akan terjadi (26). Pengonsumsian alkohol secara terus menerus dalam jumlah banyak dapat mengubah zat kimia otak, khususnya penurunan kadar serotonin, sehingga akan memicu terjadinya gangguan depresi. Selain karena ketidakseimbangan neurotransmitter inhibitorik dan eksitatorik, alkohol juga dapat merusak hemisfer otak sebelah kanan yang terlibat dalam pemrosesan rangsangan emosional non-verbal. Hal ini membuat individu dengan adiksi alkohol sering mengalami kesulitan atau kesalahan dalam menafsirkan ekspresi dengan benar, sehingga membuat ia merasa terluka, teraniaya, atau terancam oleh orang lain disekitarnya tanpa alasan yang jelas $(23,24)$.

Faktor psikologis memegang peranan penting dalam kaitannya dengan dampak adiksi alkohol. Hasil penelitian ini menunjukkan bahwa domain 2 (aspek psikologis) memiliki nilai rata-rata lebih rendah dibandingkan dengan tiga domain lainnya, yaitu sebesar $54,00 \pm 12,906$. Fakta tersebut sejalan dengan penelitian yang dilakukan oleh Saatcioglu et al. pada tahun 2008 yang membahas mengenai perbedaan kualitas hidup antara individu yang hanya mengalami adiksi alkohol, adiksi alkohol dengan gangguan depresi, dan adiksi alkohol dengan gangguan cemas. Adiksi alkohol yang disertai dengan adanya gejalagejala gangguan depresi maupun cemas akan menyebabkan peningkatan dampak negatif yang ditimbulkan, sehingga pada akhirnya menyebabkan semakin buruk pula kualitas hidupnya (22).

Pada aspek hubungan sosial, terdapat berbagai faktor, salah satunya dapat dilihat dari hubungan personal seseorang dengan keluarganya. Hasil penelitian ini menemukan bahwa individu yang mengalami adiksi alkohol memiliki kecenderungan 31 kali lebih tinggi untuk memiliki kualitas hidup yang buruk pada aspek hubungan sosial dibandingkan dengan individu yang tidak mengalami adiksi alkohol. Kajian sebelumnya menemukan asosiasi yang kuat antara adiksi alkohol dan Kekerasan dalam Rumah Tangga (KDRT), probabilitas seseorang melakukan KDRT akan melonjak menjadi 19 kali lebih tinggi di saat seseorang mengonsumsi alkohol dibandingkan dengan tidak mengonsumsi alkohol. Adiksi alkohol dapat mengurangi kontrol diri seseorang, yang pada akhirnya menyebabkan hilangnya kemampuan individu untuk menyelesaikan sebuah konflik tanpa kekerasan. Teori ini berdasarkan pada hipotesis disinhibisi, yaitu alkohol akan melemahkan mekanisme di otak yang berfungsi untuk menahan perilaku agresif atau impulsif. Teori ini juga menyatakan bahwa efek negatif alkohol dapat mengganggu persepsi individu mengenai penilaian orang lain terhadap dirinya, yang pada akhirnya dapat memicu terjadinya KDRT (27). Dapat disimpulkan bahwa seseorang dengan adiksi alkohol memiliki risiko lebih tinggi untuk melakukan KDRT dibandingkan dengan individu yang tidak mengalami adiksi alkohol, yang akan berdampak pada perburukan kualitas hidup (28).

Hasil penelitian menunjukkan bahwa individu yang mengalami adiksi alkohol memiliki kecenderungan 8 kali lebih tinggi untuk memiliki kualitas hidup yang buruk dibandingkan dengan individu yang tidak mengalami adiksi alkohol pada aspek lingkungan. Menurut WHO, masalah finansial dapat menjadi salah satu masalah yang dapat menentukan tingkat kualitas hidup seseorang khususnya pada domain 4 WHOQOL-BREF $(13,29)$. Penelitian yang dilakukan oleh Rehm mengungkapkan bahwa adiksi alkohol dapat menyebabkan seseorang menjadi kurang produktif dibandingkan dengan individu yang tidak mengonsumsi alkohol. Hal ini dapat terjadi karena dampak alkohol bagi tubuh pengonsumsinya, terutama dalam segi fisik dan mental. Adanya gangguan fisik ataupun mental ini mengakibatkan terjadinya keterbatasan dalam melakukan aktivitas sehari-hari. Ketidakproduktifan ini menyebabkan berbagai masalah di tempat kerja dan membuat performa kerja menjadi buruk bahkan dipecat dari pekerjaannya (30). Individu yang tidak bekerja atau bekerja dengan pendapatan minimal cenderung memiliki keterbatasan finansial yang dapat menyebabkan berbagai masalah dalam kehidupannya. Mereka cenderung mencari pelarian dengan mengonsumsi alkohol untuk mengatasi keterbatasan finansialnya tersebut, karena hilangnya interaksi sosial, sehingga mereka tidak dapat berbagi masalah dengan teman-teman sekitarnya (29). Individu yang bekerja memiliki kehidupan sosial yang lebih baik 
karena ia selalu berinteraksi dengan teman kerjanya dan dapat berbagi mengenai masalah dalam kehidupan yang ia jalani. Hal ini akan menurunkan perasaan-perasaan negatif seseorang yang diakibatkan oleh masalah seharihari, sehingga tidak menyebabkan penurunan kualitas hidup yang signifikan (31).

\section{DAFTAR PUSTAKA}

1. World Health Organization. Global Status Report on Alcohol and Health 2014. Geneva: World Health Organization; 2014.

2. Evren C, Dalbudak E, and Evren B. Childhood Trauma and Quality of Life among Alcohol Dependent Men. Anatolian Journal of Psychiatry. 2011; 12(4): 245252.

3. Rice KG and Van Arsdale AC. Perfectionism, Perceived Stress, Drinking to Cope, and Alcohol-Related Problems among College Students. Journal of Counseling Psychology. 2010; 57(4): 439-450.

4. Ariani A and Yosoprawoto M. Usia Anak dan Pendidikan Ibu sebagai Faktor Risiko Gangguan Perkembangan Anak. Jurnal Kedokteran Brawijaya. 2013; 27(2): 118-121.

5. McCrory EJ and Mayes L. Understanding Addiction as a Developmental Disorder: An Argument for a Developmentally Informed Multilevel Approach. Current Addiction Reports. 2015; 2(4): 326-330.

6. Kementrian Kesehatan Republik Indonesia. Riset Kesehatan Dasar Tahun 2007. Jakarta: Kementrian Kesehatan Republik Indonesia; 2008.

7. Agrawal A, Heath AC, and Lynskey MT. DSM-IV to DSM-5: The Impact of Proposed Revisions on Diagnosis of Alcohol Use Disorders. Addiction. 2011; 106(11): 1935-1943.

8. Foster JH, Powell JE, Marshall EJ, and Peters TJ. Quality of Life in Alcohol-Dependent Subjects - A Review. Quality of Life Research. 1999; 8(3): 255261.

9. da Silva Lima AF, Fleck M, Pechansky F, de Boni R, and Sukop P. Psychometric Properties of the World Health Organization Quality of Life Instrument (WHOQOL$B R E F)$ in Alcoholic Males: A Pilot Study. Qual Life Res Dordr. 2005; 14(2): 473-478.

10. Srivastava S and Bhatia MS. Quality of Life as an Outcome Measure in the Treatment of Alcohol Dependence. Industrial Psychiatry Journal. 2013; 22(1): 41-46.

11. Reaney MD, Martin C, and Speight J. Understanding and Assessing the Impact of Alcoholism on Quality of Life: A Systematic Review of the Content Validity of Instruments Used to Assess Health-Related Quality of Life in Alcoholism. The Patient: Patient-Centered Outcomes Research. 2008; 1(3): 151-163.

12. Williams N. The CAGE Questionnaire. Occupational Medicine. 2014; 64(6): 473-474.

13. Kirouac M, Stein ER, Pearson MR, and Witkiewitz K. Viability of the World Health Organization Quality of Life Measure to Assess Changes in Quality of Life Following Treatment for Alcohol Use Disorder. Quality of Life Research. 2017; 26(11): 2987-2997.

14. Yamamoto T. Quality of Life: Policy Concept and Reality. Japanese Journal of Political Science. 2014; 15(2): 163-182.
Dapat disimpulkan bahwa individu dengan adiksi alkohol akan memiliki kualitas hidup yang lebih buruk pada semua domain (fisik, psikologis, sosial, dan lingkungan) dibandingkan dengan individu yang tidak mengalami adiksi alkohol. Dampak terburuk adiksi alkohol yang ditemukan adalah pada domain psikologis.

15. Faller S, da Rocha NS, Benzano D, et al. Factors Associated With a Quality of Life Decrease in Alcoholic Patients Who Sought Treatment. Journal of Addiction Research \& Therapy. 2015; 6(2): 1-6.

16. Campêlo SR, Barbosa MA, Dias DR, Caixeta CC, Leles $\mathrm{CR}$, and Porto CC. Association between Severity of Illicit Drug Dependence and Quality of Life in a Psychosocial Care Center in Brazil: Cross-Sectional Study. Health and Quality of Life Outcomes. 2017; 15(1): 223 (1-10).

17. Daeppen JB, Faouzi M, Sanchez N, Rahhali N, Bineau $\mathrm{S}$, and Bertholet N. Quality of Life Depends on the Drinking Pattern in Alcohol-Dependent Patients. Alcohol and Alcoholism. 2014; 49(4): 457-465.

18. Balhara YP, Singh S, Modak T, and Sarkar S. A CrossSectional Study to Assess Disability and Its Correlates among Treatment Seeking Individuals with Alcohol Use Disorders. Indian Journal of Psychological Medicine. 2017; 39(1): 40-45.

19. Shield KD, Parry C, and Rehm J. Chronic Diseases and Conditions Related to Alcohol Use. Alcohol Research Current Review. 2014; 35(2): 155-171.

20. Fullwood D. Alcohol-Related Liver Disease. Nursing Standart. 2014; 28(46): 42-47.

21. Ceni E, Mello T, and Galli A. Pathogenesis of Alcoholic Liver Disease: Role of Oxidative Metabolism. World Journal of Gastroenterology. 2014; 20(47): 1775617772.

22. Saatcioglu O, Yapici A, and Cakmak D. Quality of Life, Depression and Anxiety in Alcohol Dependence. Drug and Alcohol Review. 2008; 27(1): 83-90.

23. Getachew B, Hauser SR, Taylor RE, and Tizabi Y. Alcohol-Induced Depressive-Like Behavior is Associated with Cortical Norepinephrine Reduction. Pharmacology, Biochemistry \& Behavior. 2010; 96(4): 395-401.

24. Sari Y, Johnson VR, and Weedman JM. Role of The Serotonergic System in Alcohol Dependence: From Animal Models to Clinics. Progress in Molecular Biology and Translational Science. 2011; 98: 401-443.

25. Kuria MW, Ndetei DM, Obot IS, et al. The Association between Alcohol Dependence and Depression Before and After Treatment for Alcohol Dependence. ISRN psychiatry. 2012; 2012: 1-6.

26. Levola J, Aalto M, Holopainen A, Cieza A, and Pitkänen T. Health-Related Quality of Life in Alcohol Dependence: A Systematic Literature Review with a Specific Focus on the Role of Depression and Other Psychopathology. Nordic Journal of Psychiatry. 2014; 68(6): 369-384.

27. Zaleski M, Pinsky I, Laranjeira R, Ramisetty-Mikler S, and Caetano R. Intimate Partner Violence and Alcohol Consumption. Rev Saúde Pública. 2010; 44(1): 53-59.

28. Lucena KDT, Vianna RPT, Nascimento JAD, Campos HFC, and Oliveira ECT. Association between Domestic Violence and Women's Quality of Life. Revista Latino- 
Americana de Enfermagem. 2017; 25: e2901

29. Serido J, Lawry C, Li G, Conger KJ, and Russell ST. The Associations of Financial Stress and Parenting Support Factors with Alcohol Behaviors During Young Adulthood. Journal of Family and Economic Issues. 2014; 35(3): 339-350.

30. Rehm J. The Risks Associated with Alcohol Use and
Alcoholism. Alcohol Research \& Health. 2011; 34(2): 135-143.

31. Koinis A, Giannou V, Drantaki V, Angelaina S, Stratou E, and Saridi M. The Impact of Healthcare Workers Job Environment on Their Mental-Emotional Health. Coping Strategies: The Case of a Local General Hospital. Health Psychology Research. 2015; 3(1): 12-17. 